\title{
Title:
}

\section{Surprises in cecal intubation: foreign bodies in the colon}

\section{Authors:}

Isabel Pérez Valle, Pedro Amor Martín, Ángel Cano Abascal

DOI: $10.17235 /$ reed.2021.8155/2021

Link: PubMed (Epub ahead of print)

Please cite this article as:

Pérez Valle Isabel, Amor Martín Pedro, Cano Abascal Ángel . Surprises in cecal intubation: foreign bodies in the colon . Rev Esp Enferm Dig 2021. doi: 10.17235/reed.2021.8155/2021.

This is a PDF file of an unedited manuscript that has been accepted for publication. As a service to our customers we are providing this early version of the manuscript. The manuscript will undergo copyediting, typesetting, and review of the resulting proof before it is published in its final form. Please note that during the production process errors may be discovered which could affect the content, and all legal disclaimers that apply to the journal pertain. 
Surprises in cecal intubation: foreign bodies in the colon

Isabel Pérez Valle. Digestive System Clinical Management Unit. Hospital Álvarez Buylla (Mieres, Asturias) pvalle.isabel@gmail.com

Pedro Amor Martín. Digestive System Clinical Management Unit. Álvarez Buylla Hospital (Mieres, Asturias).

Ángel Cano Abascal. Neurology Service. Cabueñes University Hospital (Gijón, Asturias).

\section{CLINICAL CASE}

We present the case of a 70-year-old man who came for colonoscopy on an outpatient basis after being admitted months earlier for a subocclusive condition that was resolved through conservative treatment.

His medical background includes a laparotomy in 1979 due to a duodenal ulcer as well as a subsequent intervention to release adhesions.

Cecal intubation was achieved with difficulty due to the patient's adhesive syndrome. Once we reached the cecal fundus, we observed an elongated metallic object, with a length of about $2 \mathrm{~cm}$, which we extracted by means of a polypectomy snare.

When the patient was questioned again after the colonoscopy, he mentioned that two weeks before he had undergone maxillofacial surgery for dental implants and that he had had the sensation of swallowing a foreign body without any subsequent clinical consequences.

DISCUSSION

Foreign body ingestion is the second leading cause of endoscopic emergencies in adults in our hospitals, with dental prostheses being one of the most frequent foreign bodies (1). The risk varies considerably depending on the characteristics of said objects and where they are lodged. However, we should never trivialize the situation, since it is mandatory to consider the risk of perforation or, less frequently, of obstruction or haemorrhage (2). According to clinical guidelines, blunt foreign bodies with an elongated shape, smaller than $5 \mathrm{~cm}$ can be treated conservatively. These general rules do not apply to patients with known pathology which may make the expulsion of the foreign body more difficult $(3,4)$. 


\section{BIBLIOGRAPHY}

1. Santander-Flores SA, Mata-Quintero CJ, O'Farrill-Anzures R, González-Villegas $P$, et al. Accidental ingestion of dental prostheses; 2 scenarios in the management and outcome. Case reports. Cir. 2017 Jul-Aug;85(4):350-355. Spanish. doi: 10.1016/j.circir.2016.04.003. Epub 2016 Jun 16. PMID: 27320649.

2. García-López S, Aspuru K. Foreign bodies. Foreign body ingestion. Montoro M, García Pagán JC (eds) Gastroenterology and Hepatology, common problems in clinical practice. 2nd ed. Jarpyo Editores: Madrid, Barcelona p 229-2242.

3. Birk M, Bauerfeind P, Deprez PH et al. Removal of foreign bodies in the upper gastrointestinal tract in adults: European Society of Gastrointestinal Endoscopy (ESGE) Clinical Guideline. Endoscopy. 2016 May;48(5):489-96. doi: 10.1055/s-0042-100456. Epub 2016 Feb 10. PMID: 26862844.

4. Yu M, Liu D, Tan Y. Patients with upper gastrointestinal foreign bodies are more likely to consult later and with a higher rate of hospitalization during the COVID-19 pandemic. Rev Esp Enferm Dig. 2021 Feb;113(2):148. doi: 10.17235/reed.2020.7593/2020. PMID: 33371711.

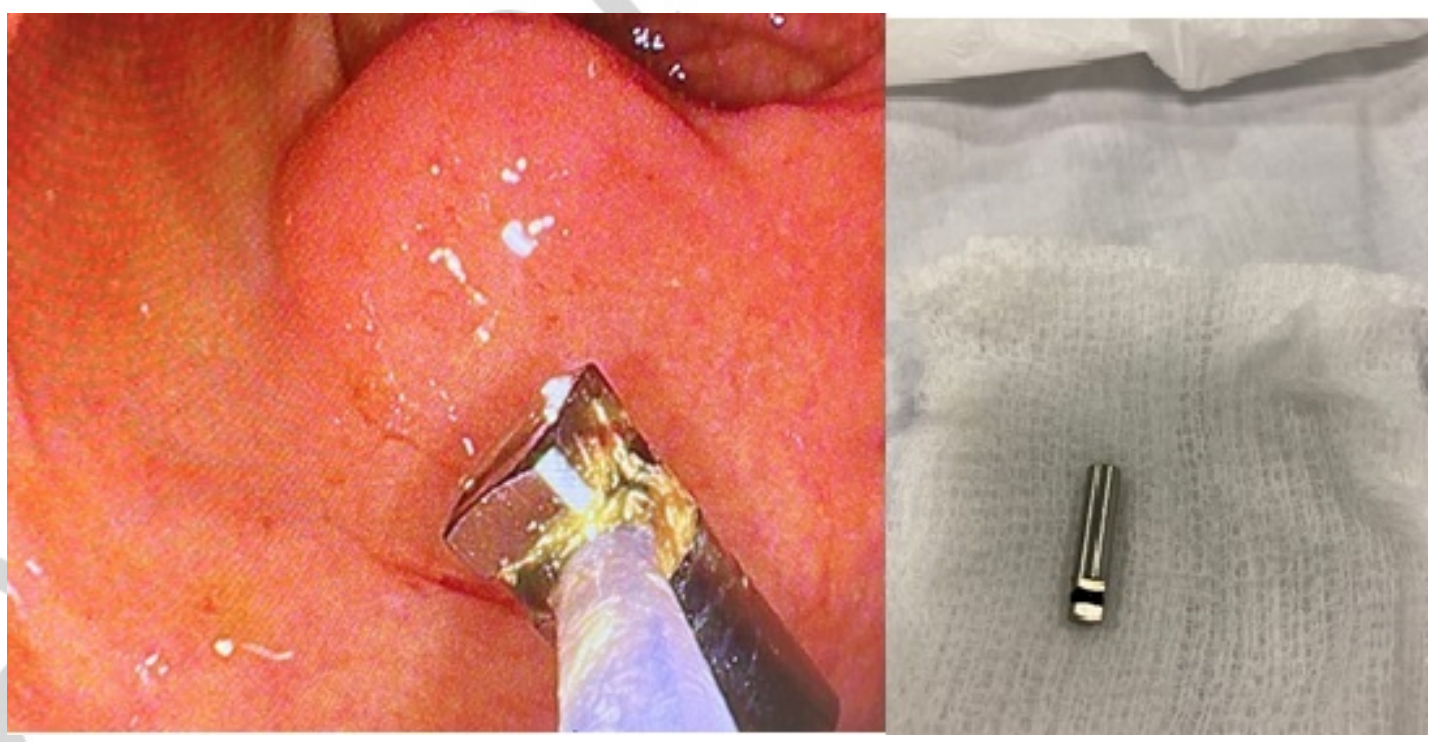

Figure 1. 